\title{
Pesantren as a Halal Center Institution Towards Religious Tourism Development
}

\author{
Tata S. Purnama ${ }^{1 *}$, Zirmansyah ${ }^{2}$, Iyan Fitriyana ${ }^{3}$ \\ 1,2 Department of Islamic Education, Faculty of Psychology and Education, Universitas Al Azhar Indonesia \\ Jl. Sisingamangaraja No. 2, Selong, Kec. Kebayoran Baru, Kota Jakarta Selatan, DKI Jakarta 12110, Indonesia \\ ${ }^{3}$ Department of Islamic Education, STAI Wasilatul Falah Rangkasbitung \\ JL. Tb. Hasan, Jatimulya Ciseke, Lebak Banten, Rangkasbitung Timur, Rangkasbitung, Kabupaten Lebak, \\ Banten 42300, Indonesia \\ e-mail: tata.septayuda@uai.ac.id ${ }^{* 1}$, zirmansyah@uai.ac.id ${ }^{2}, \underline{\text { iyan fitriyana@yahoo.co.id }}^{3}$
}

* Corresponding Author

Received: January 06, 2021; Accepted: February 23, 2021

\begin{abstract}
The pesantren institutions have never lost interest from the young generation. An old pesantren continues the process, and new pesantren keep appearing. The education system and the institutions for pesantren are growing rapidly, as supported by facilities, infrastructure, and curriculum. They are adapted constanly according to the times. The halal center discourse is developing in the global world. It has made the continue of pesantren to offer applicative ideas. Then the institutions can become the promising center for religious tourism. This study used qualitative literature study and interviews to collect data that related to religious tourism in pesantren. It can be concluded that there are five potentials for developing religious tourism and halal centers in pesantren; such as the intrinsic value of the pesantren, the pattern of life, the environment and the surrounding community, the sacredness, and the spiritual atmosphere; and pesantren religious tourism aspect.
\end{abstract}

Keywords: halal pesantren, religious tourism.

\section{Introduction}

The history of pesantren in Indonesia is closely related to the history of Islam itself. Since the 16th century, there is a strong opinion that pesantren is a dynamist in the historical process of national struggle (Ambary, 2001). From the historical perspective, pesantren does not only contain Islamic meaning but also contain Indonesian indigenous, because the similar institutions existed during the influence of Hindu-Buddhist (Madjid, 1992).

Another term for pesantren is Pondok. We know the terms of Pondok Tebuireng, Pondok Gontor, Pondok Krapyak, or Pesantren Tebuireng, Pesantren Gontor, Pesantren Krapyak, which did not show any difference in meaning. The term of pesantren is used as a synonym for pondok or all at once. It also becomes a boarding school (Zarkasyi, 2006). In essence, every pesantren has learning model as known as madrasah.

Pesantren is usually defined as an Islamic education and teaching institution. There are five main elements (Dhofier, 2011). The first is the pondok or dormitory for the students. The second is the mosque as being a place for doing the ritual activities and for teaching learning activity at the same time. The third is santri. It is the students' term who come to the Kiai for studying religious and sciences. The fourth is Kiai. He is as the main figure who provides religious instruction and guidance. The fifth is the study of the classical textbooks (Kitab Kuning) of the main issues in Islamic teachings (Figure 1).

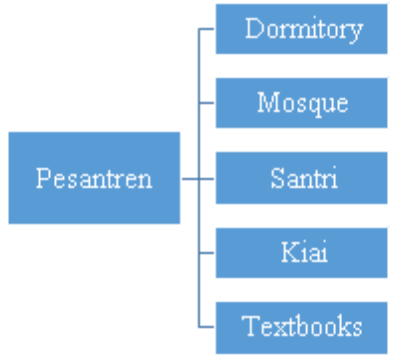

Figure 1. Element of Pondok Pesantren 
According to Jabali \& Jamhari (2002), these five elements constitute the basic institutional structure of all traditional pesantren in Indonesia. In this case, the traditional pesantren is understood as the educational activities that focuses on tafaqquh fiddin entirely. They are the deepening experience, expanding knowledge, and mastering the treasures of Islamic teachings (Jabali \& Jamhari, 2002).

KH Imam Zarkasyi as the founder of Pondok Modern Gontor in East Java defines pondok pesantren. The first definition is Kiai. The Kiai is always as the central figure in pondok pesantren. The second is Santri. The santri is someone or a group of students who pursue knowledge in pondok pesantren. Usually, they are accounted as an indicator of the progress and popularity. The third is Pondok. Pondok is a dormitory where the santri lived and studied under the guidance of the kiai. The fourth is Mosque. Mosque constitutes as the main resource and space for the Kiai carries out his obligation to educate and train his santri, to do the ibadah (divine certitude) and learning Islamic textbooks and to conduct social activities. The subject taught in pesantren is not only the kitab kuning (Zarkasyi, 2006).

According to Education Management Information System (EMIS), Directorate General of Islamic Institution, the total number of Pondok Pesantren in Indonesia is 28,984. It is very strategic potential for Indonesian nation (Ditpdpontren, 2018).

Pesantren in Indonesia are classified as modern and traditional educational institutions. The modern pesantren usually follows the national school curriculum. On the other hand, the traditional pesantren focuses on religious subjects entirely. The majority of pesantren in Indonesia are traditional and the independent of formal government control (Tan, 2012). Another study shows that the characteristics of pesantren education are divided into three categories. the first is traditional pesantren (salaf). The model of the pesantren teaches kitab kuning as the dominant subject. The second is the modern pesantren (khalaf). It is led by the Pesantren Gontor in East Java, with having the teaching system such as the school level. The students also learn mathematics or science. The third is integrated pesantren. Several pesantren were originally traditional that switched to the modern system. It combines the characteristics of traditional, modern pesantren and the national education system (Purnama, 2016).

The largest population of pesantren is in the Provinces of West Java, East Java, Central Java and Banten. The amount of then are 78.60\% of the total Pesantren in Indonesia. With details of West Java is 7,624 (28.00\%), East Java is 6,003 (22.05\%), Central Java is 4,276 (15.70\%) and, Banten is 3,500 (12.85\%). From all the existing Pesantren, based on the typology of Pesantren, there are 14,459 (53.10\%) traditional Pesantren, 7,727 (28.38\%) modern and, 5.044 (18.52\%) as Integrated Pesantren (Figure 2).

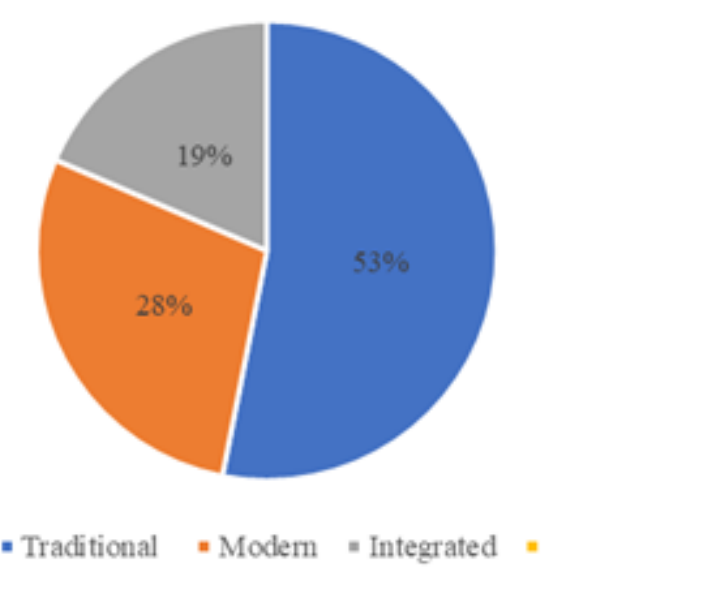

Figure 2. Typology of Pondok Pesantren

In the 75 years of Indonesia's independence, it appears that the world of pesantren has never lost interest from the young generation. An old pesantren continues the process and a new pesantren continue to emerge. Along with that, education systems and institutions labeled modern develop rapidly. They are supported by facilities, infrastructure and curriculum that have evaluated. In global development through halal issues, pesantren continues to offer applicative ideas, such as pesantren as a center for religious tourism or halal tourism. 
Halal tourism has been introduced since 2000 from an organization meeting discussions of the Islamic Cooperation. This tourism concept aims to motivate tourists to get happiness and blessings from Allah (Chairilsyah, 2019). The Ministry of Tourism and Creative Economy of the Republic of Indonesia defines that halal tourism as an activity that is supported by various facilities and services provided by the community, business people, government that complies with Islamic regulations (Andriani et al., 2015).

Meanwhile, the definition of halal tourism according to Sofyan (2012) is all tourism activities as mentioned above without leaving Islamic sharia values. According to Septiadi et al. (2020) Islam has strict rules regarding to human life that separates halal and haram. Halal can be defined as every object or activity that is allowed in Islamic rule.

The Global Muslim Travel Index as a forum that focuses on developing the world halal tourism shows that religious tourism is tourism that is carried out by Islamic principles to provide friendly facilities and services for Muslim tourists (GMTI, 2016). In the context of introducing the concept of halal, pesantren institutions function as facilitators that can work with the government to teach their students about the concept of halal (Qomaro, 2018).

The increasing religious awareness among Muslims is marked by the existence of efforts to adapt their lives to the values that exist in the teachings of Islam itself. The word of halal comes from Arabic halla, yahillu, hillan, which means to free, let go, break, and allow (Dahlan, 1997). The word is the main source that is not only related to food or food products, but also enters all aspects of life, such as banking and finance, cosmetics, work, tourism, and other. Meanwhile, halal tourism is one of the emerging concepts related to halal and has been defined in various ways by experts (Satriana \& Faridah, 2018).

Based on the existing literature, the concept of tourism is very diverse among nature tourism, marine tourism, shopping tourism, cultural tourism, educational tourism, health tourism, culinary tours, ancient tours, and spiritual tourism (Badudu \& Zain, 2001). From the notes above, the presence of pesantren can be categorized as spiritual tourism which is currently being used as the object of its implementation. Several Islamic boarding schools that call themselves centers of halal tourism are (1) Pesantren Wisata Daar el Qolam La Ghofla Cisarua Puncak, West Java; (2) Pesantren Sakinah La Lahwa, Tanjung Lesung, Pandeglang, Banten; (3) Pesantren Wisata La Tansa 5, Lebak Banten, and (5) Pondok Pesantren Wisata Al Mizan 3, Pandeglang Banten.

Generally, religious tourism and conventional tourism are no different. They only need for tour packages, accommodation, food and beverages in fulfilling Islamic values. Pesantren as a halal center that has the potential to be developed into a center of religious tourism. The contents are framed in Islamic values.

In this research, the main point to be noted is the word of safar (traveling) which comes from revelation. According to Summa (2017) in the al-Quran, the word safar is found at several forms repeated 7 times in 6 surah and 7 verses. Especially in the text and context of the verses that relate to travel affairs which are closely related to mahdhah worship, especially fasting (QS. 2: 184 and 185) and wudhu and tayamum (QS. 4: 43 and QS. 5: 6); besides anything related to business aspect (QS 2: 283), traveling to the battlefield (QS. 9: 42) as well as the stories of the long journey of Prophet Musa (QS. 18: 62) and the people of Saba (QS. 34: 19).

\section{Materials and Methods}

This research used a qualitative descriptive method. It is the study type that is not applying statistical procedures or other methods of measurement related to the processing of data quantification (Creswell, 2009). Literature sources were such as scientific books, study reports, scientific articles, theses, regulations, interviews, and other written or electronic sources are gathered and carefully selected to be studied (Ceswell, 2014). The qualitative descriptive method is intended to sharpen the data obtained to obtain objective and rational generalization to decide what the appropriate strategic steps to describe pesantren as halal center institution towards religious tourism development. In this research, by designating the case study at the La Tansa Islamic Boarding School at Lebak Banten, was analyzed to produce the findings that were useful for Islamic educational institutions. 


\section{Results and Discussion}

The Ministry of Tourism and Creative Economy of the Republic of Indonesia has formed a special agency, namely the Halal Tourism Development Acceleration Team/Tim Percepatan Pembangunan Pariwisata Halal (TP3H). The team is given the authority to help the government map, develop and provide regional guidelines that have potential for halal tourism.

TP3H's position is a political policy. Then the institution is currently inactive. However, the government's concentration on halal development issues have been carried out for a long time. The Indonesian Ulama Council (MUI), which was founded in 1975, as the government partner is an institution that is very concern about the development of halal industry in Indonesia. This task is carried out primarily by the three institutions under MUI, namely Dewan Syariah Nasional (DSN), the Komisi MUI Fatwa, and the LPPOM MUI.

Table 1. General Criteria for Halal Tourism

\begin{tabular}{ll}
\hline \multicolumn{1}{c}{ Category } & \multicolumn{1}{c}{ Indicator } \\
\hline Tourism Destinations & $\begin{array}{l}\text { There is various of tourist activities, arts and culture that do not } \\
\text { contain the pornography and idolatry } \\
\text { The tour guide is dressed in Muslim attire and has polite appearance } \\
\text { Having the rules for visitors to not wear skimpy dressed }\end{array}$ \\
\hline Hotel & Halal food is available \\
& There are facilities that can ease to carry out worship, such as \\
& mosques, prayer rooms and purification facilities \\
& Non-halal activities such as gambling, alcoholic drinks, and \\
discotheques are not available & \\
\hline Travel agency & $\begin{array}{l}\text { Providing tour packages that comply with the general criteria for Halal } \\
\text { tourism } \\
\text { Does not offer any non-halal activities } \\
\text { Having the list of halal food and beverage businesses }\end{array}$
\end{tabular}

Source: Halal Tourism Development Acceleration Team/Tim Percepatan Pembangunan Pariwisata Halal (Widhasti et al., 2017).

Religious tourism has a role in developing human religious awareness. Even tourism in Islam is an inseparable part of worship such as the pilgrimage that carries out processions and holy trips (Karim, 2017). Referring to the formulation of the criteria for the Halal Tourism Development Acceleration Team (TP3H) of the Ministry of Tourism and Creative Economy, several pesantren can be categorized as general criteria for halal tourism as well as Islamic educational institutions (Table 2).

Table 2. Pesantren as Halal Centers and Religious Tourism

\begin{tabular}{|c|c|}
\hline Category & Indicator \\
\hline Intrinsic values & $\begin{array}{l}\text { Formation to become a personal Muslim; the noble character, sound body, } \\
\text { broad knowledge, and independent mind } \\
\text { Having the rules for visitors not to wear skimpy dressed }\end{array}$ \\
\hline Pattern of life & $\begin{array}{l}\text { Systematic polarization of life with discipline, such as a culture of queuing } \\
\text { Halal food is available according to Islamic law }\end{array}$ \\
\hline Environment & $\begin{array}{l}\text { There are facilities that make it easy to carry out worship, such as } \\
\text { mosques, prayer rooms and purification facilities } \\
\text { Located in a rural area synonymous with rice fields and plantations, } \\
\text { mountains, and beaches }\end{array}$ \\
\hline $\begin{array}{l}\text { Spiritual } \\
\text { Atmosphere }\end{array}$ & $\begin{array}{l}\text { Kiai, ustadz, mosque, male and female dormitory are sacred values. } \\
\text { As the center for worship activities (sholat, i'tikaf, tadarus), including } \\
\text { religious events (barzanji, Islamic art performances) }\end{array}$ \\
\hline $\begin{array}{l}\text { Aspects of } \\
\text { religious tourism }\end{array}$ & $\begin{array}{l}\text { The tour guide is dressed according to the shari'a and has polite } \\
\text { appearance } \\
\text { Providing tour packages that comply with the general criteria for Halal } \\
\text { tourism }\end{array}$ \\
\hline
\end{tabular}

Source: Karim, A. Mafatihullah. Interview. 30 November 2020 


\subsection{The Intrinsic Values of Pesantren}

The main values inside pondok pesantren are inspired strongly by Panca Jiwa or Five spirits. They are sincerity, simplicity, self-reliance, Islamic Brotherhood, and accountable freedom (Masqon, 2014). These five souls are always upheld and used as the reference for the creation of the education system and the value of life in pondok pesantren (Alhamuddin \& Hamdani, 2018). In addition to these values, education in Islamic boarding schools is emphasized on the formation of Muslim personalities with four mottos, namely; the noble character, body sounds, broad knowledge, and independent mind (Alhamuddin \& Hamdani, 2018). Based on five spirits (panca jiwa) and four mottos that are intrinsic values, the efforts of the La Tansa Islamic Boarding School as a tourism-based educational institution confirms the seven charms (sapta pesona) as an absolute requirement for tourism, namely: safety, comfortable, orderly, beautiful, cool, friendly, and memorable (Karim, 2017).

\subsection{Pesantren Life Patterns}

According to Karim, the polarization of pesantren life is systemized with a discipline that gives rise to the separate lifestyle or culture for the students, such as the culture of queuing. This is not because of the lack of pesantren facilities, but the waekness of pesantren management (Karim, 2017).

Everything is deliberately formed through the concept of education even though it starts with coercion then becomes accustomed and finally implemented with full awareness. Queuing is the noble act and deliberates meaning that we appreciate other human beings as equals. Queuing up is a matter of how to respect others (Chairilsyah, 2019). We can see long queues occurring in restaurants, cinemas, banks, entertainment venues, and so on. Queuing culture trains patience, consideration, please help. Also it turns out in Japan. The culture of queuing is the pride of its residents. The whole world admires, praises and learns the queuing culture of Japanese people (Hoi, 2020). In introducing the concept of halal, Pesantren function is as a facilitator that can cooperate with the government to develop halal center. As an Islamic educational institution, almost all aspects of pesantren are oriented towards the halalness of the products. For example, the availability of halal food and drink.

\subsection{Pesantren Environment and Surrounding Society}

The education system at pondok pesantren keeps on 24 hours in the dormitory environment. Such education certainly covers the wider variety of fields, including the aspects of spiritual, intellectual, moral-emotional, social, and physical education (Alhamuddin \& Hamdani, 2018). Thus, everything is seen, heard, and considered education that can be implanted in the soul of the students to shape their personality in terms of reason, morals, body, and other educational factors. From the environmental aspect of the surrounding society, according to Karim (2020), the nature pesantren usually presents the local culture and aesthetic charm. Pesantren La Tansa that located in rural area, is synonymous with rice fields and plantations, mountains and beaches. Around the Pesantren, we listen the chirping birds, frogs, the sound of goats, buffalo, the splashing of river water and the cool air. Lately, the charm of traditional and natural tourism has become the trend. According to Karim (2017), even though the Pesantren is in the city, it is still rich in imagination and creativity. It is because, the students can explore the art creations, skills, craft products, culinary and services tibbunnaby. The realization of friendly-environment Pesantren can be done when we understand the typology of Pesantren as an educational institution that differs from other formal educational institutions (Herdiansyah et al., 2018).

\subsection{The Sacredness and Spiritual Atmosphere}

In the realm of pesantren, Kiai, Ustadz, mosques, male-female dormitories have sacred values. Kiai is an exemplary figure. Many people not only make pilgrimages to sacred graves but also want to visit and ask the Kyai's advice (Karim, 2017). Meanwhile, Ustadz is the second figure to become respected Kiai confidant. To fight against, the Ustadz means the same as fighter as the Kyai. A mosque is not only a place for worship, ittikaf, and tadarusan, but also become a place that is often used in religious events (barzanji, sholawatan, Islamic arts). Male-female dormitories are not in the same place to enter carelessly. The is the taboo for male students to enter female dormitories and vice versa (Karim, 2020).

\subsection{Religious Tourism Program}

As an educational institution that has gone public, Pondok Pesantren La Tansa is very busy with the arrival of guests from various communities. This can be utilized by pesantren which functions to manage human resources for training and education related to religious tourism program, including; (a) taqorrub, namely making the habit of praying in congregation five times a day, tadarus al-Quran, 
shalat duha and tahajjud; (b) tafakkur, by following taushiyah, the study of interpretation (kajian tafsir), practice of worship, training on motivation; (c) tadabbur, can be done through physical exercises such as archery, horse riding, swimming, out bonding, rafting, hot springs. Meanwhile, Pondok pesantren based on religious tourism that has been established include (1) Pesantren Wisata Daar el Qolam La Ghofla at Cisarua Puncak, West Java; (2) Pesantren Sakinah La Lahwa at Tanjung Lesung, Pandeglang, Banten; (3) Pesantren Wisata La Tansa 5 ar, Lebak Banten, and (5) Pondok Pesantren Wisata Al Mizan 3 at Pandeglang Banten.

\section{Conclusion}

Halal (religious) tourism is a study that has developed recently. The use of terminology related to varying halal tourism is still debatable. The development of halal tourism needs to be done. One of them is by making the trend as the center of halal implementation. Until now, the research related to halal tourism is still limited, especially in Indonesia. The result of this study shows that pesantrens are not only as the center of Islamic activities, but also as religious tourism destination that have strong appeal. With the five potentials above, pesantren has the characteristics that other tourist objects do not have. It is not surprising that those who are educated and traveled on religion in the pesantren come from various regions and various backgrounds. Apart from registering as students, those who come to the pesantren are often presented by the researchers, tourists, or agency officials who want to see the laboratory of life intimately.

\section{References}

Alhamuddin, \& Hamdani, F. F. R. S. (2018). Hidden Curriculum: Polarisasi Pesantren dalam Upaya Membentuk Kesalehan Individu Dan Sosial (Case Study Pondok Modern Darussalam Gontor Ponorogo). AL-MURABBI: Jurnal Studi Kependidikan Dan Keislaman, 5(1), 50-65. http://ejournal.kopertais4.or.id/mataraman/index.php/murabbi/article/view/3351

Ambary, H. M. (2001). Menemukan Peradaban: Jejak Arkeologis dan Historis Islam Indonesia (2nd ed.). Jakarta: Logos Wacana Ilmu.

Andriani, D., Khalikal, K. Akbar, Aqmarina, L., \& Nurhayati, T. (2015). KAJIAN PENGEMBANGAN WISATA SYARIAH Susunan Anggota Kelompok Kerja: Laporan Akhir Kajian Pengembangan Wisata Syariah.

Badudu, J. S., \& Zain, S. M. (2001). Kamus umum bahasa indonesia. Jakarta: Pustaka Sinar Harapan.

Ceswell, J. W. (2014). Research design pendekatan metode kualitatif kuantitatif dan campuran Ed.4. Yogyakarta: Pustaka Pelajar.

Chairilsyah, D. (2019). Teaching Queuing Culture In Early Childhood Daviq. Jurnal Educhild (Pendidikan \& Sosial), 8(2), 53-58.

Creswell, J. W. (2009). Research Design: Qualitative, Quantitative, and Mixed Methods Approaches. In US: Sage Publication. https://doi.org/10.1080/14675980902922143

Dahlan, A. A. (1997). Ensiklopedi Hukum Islam. Jakarta: PT. Ichtiar Baru Van Hoeve.

Dhofier, Z. (2011). Tradisi Pesantren: Studi tentang Pandangan Hidup Kiyai. Jakarta: LP3ES.

Ditpdpontren. (2018). Pangkalan Data Pendidikan Diniya dan Pondok Pesantren Kementerian Agama Republik Indonesia. https://ditpdpontren.kemenag.go.id/pdpp/about

Herdiansyah, H., Sukmana, H., \& Lestarini, R. (2018). Eco-Pesantren as A Basic Forming of Environmental Moral and Theology. Kalam, 12(2), 303-326. https://doi.org/10.24042/klm.v12i2.2834

Hoi, H. (2020). Bringing the Hidden Beauties and Culture of the Japanese Into Softskill Classes. International Journal of Advanced Research in Engineering and Technology (IJARET), 1(8), 16. https://doi.org/10.34218/IJARET.11.8.2020.001

Jabali, F., \& Jamhari. (2002). IAIN dan Modernisasi Islam di Indonesia. Logos Wacana Ilmu.

Karim, A. M. (2017). Pesantren sebagai Pusat Wisata Religi. In A. D. Hendriawan, D. M. Darmawan, \& I. Fitriyana (Eds.), Pesona Wisata di Tanah Lebak. Humas Pemda.

Karim, A. M. (2020). Hasil Interview: Pesantren as Halal Centers and Religious Tourism, 30 November 2020

Madjid, N. (1992). Bilik-Bilik Pesantren Sebuah Potret Perjalanan. Jakarta: Paramadina.

Masqon, D. (2014). Dynamic of Pondok Pesantren As Indegenous. Edukasi, 12.

Purnama, T. S. (2016). HUT 198 Lebak: Menjadi Seribu Madrasah Berkarakter. Lebak: Humas Pemda.

Qomaro, G. W. (2018). Urgensi Partisipasi Pesantren sebagai Pusat Edukasi dan Moderasi Islam 
dalam Percepatan Pariwisata Halal di Indonesia. Proceedings of Annual Conference for Muslim Scholars, April, 445-465.

Satriana, E. D., \& Faridah, H. D. (2018). Halal Tourism: Development, Chance and Challenge. Journal of Halal Product and Research, 1(2), 32. https://doi.org/10.20473/jhpr.vol.1-issue.2.3243

Septiadi, M. A., Joharudin, A., Lestari, N. G., Fajri, R. R., \& Khendra, M. (2020). Halal Politics Role in the Fight against Vote-Buying and Hoaxes. Indonesian Journal of Halal Research, 2(2), 3339. https://doi.org/10.15575/ijhar.v2i2.8981

Sofyan, R. (2012). Prospek Bisnis Pariwisata Syariah. Republika.

Summa, M. A. (2017). Syi'ar Lebak Dalam Wisata Syar'i. In A. D. Hendriawan, D. M. Darmawan, \& I. Fitriyana (Eds.), Pesona Wisata di Tanah Lebak. Humas Pemda.

Tan, C. (2012). Islamic Education and Indoctrination: The Case in Indonesia. New York: Routledge.

Widhasti, G. B., Damayanti, C., \& Sardjono, H. S. (2017). Diplomasi Publik Pemerintah Republik Indonesia Melalui Pariwisata Halal. Jurnal Solidaritas: Ilmu-Ilmu Sosial, 1(1), 8.

Zarkasyi, A. S. (2006). Gontor dan Pembaharuan Pendidikan Pesantren. Jakarta: PT Raja Grafindo Persada.

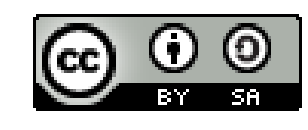

(C) 2021 by Indonesian Journal of Halal Research (IJHAR). Submitted for possible open access publication under the terms and conditions of the Creative Commons Attribution (CC BY SA) license (https://creativecommons.org/licenses/by-sa/4.0/). 